\title{
Factors affecting net interest margin of joint-stock commercial banks in Vietnam
}

\author{
PHAM HOANG AN \\ Van Hien University - hoangan.tcnh@gmail.com \\ VO THI KIM LOAN \\ Saigon University - loanct.dhsg@gmail.com
}

\section{ARTICLE INFO ABSTRACT}

Article history:

Received:

Sep. 8, 2016

Received in revised form:

Dec. 8, 2016

Accepted:

Dec. 31,2016
This study analyzes factors affecting net interest margin of joint-stock commercial banks in Vietnam. The paper uses the secondary data of 26 banks with 182 observations for the period of 2008-2014 and applies the panel data regression method. The empirical results indicate that lending scale, credit risk, capitalization, and interest rate have positive impacts on net interest margin. In contrast, managerial efficiency has a negative effect on net interest margin. However, bank size and loan to deposit ratio are statistically insignificant to net interest margin.

Keywords:

Net interest margin

Joint-stock commercial

banks

Panel data

Vietnam 


\section{Introduction}

The efficiency of banking operations has always been a problem of great concern to bank managers, as it is the key to sustainable profit, which enables the bank to develop and compete in the international environment.

A competitive banking system will create a higher efficiency and a lower NIM (Rudra $\&$ Ghost, 2004). High profit return ratio creates significant obstacles to intermediaries, such as more savings encouraged by lower borrowing interest rate and reduced investment opportunities of the banks as a result of higher lending rate (Fungáčová \& Poghosyan, 2011). Therefore, banks expect to be doing their intermediate functionality with the lowest cost possible to promote economic growth.

NIM ratio is a measure for the effectiveness as well as profitability, and a very important performance indicator because it often accounts for about $70-85 \%$ the total income of a bank. The higher this ratio is, the higher the bank's income will be. It indicates the ability of the Board of Directors and employees in maintaining the growth of incomes (mainly from loans, investments and service fees) compared with the increase in cost (mainly from interest cost for deposits, monetary market's debts) (Rose, 1999).

Therefore, research on factors that influence the net interest margin of joint-stock commercial bank is necessary. The result of this study can serve as a scientific basis for bank managers to make suitable decisions, bring good efficiency, and increase the attractiveness of their stocks.

\section{Literature review and previous studies}

\subsection{Net interest margin}

To calculate the operating effect of any bank, it is common to analyze return on equity (ROE), return on asset (ROA), net interest margin (NIM), and interest spread (Rose, 1999). Hemple et al. (1986) stated that NIM is helpful in measuring changes in interest spread and comparing profit between banks.

Net interest margin ratio is one of the most important measurements to quantify financial effectiveness in an intermediary institution (Golin, 2001). Net interest margin (NIM) is defined by the ratio of net interest income to total earning asset.

(Interest Income - Interest Expense)

\subsection{Factors influencing NIM}

Based on previous investigations in Russia, Turkey, China, Lebanon, and Fiji, we define similarities between Vietnam and these nations, and thereby suggests some factors which have impacts on net interest margin, including:

\section{Size}

Studies of Maudos and Guevara (2004) and Ugur and Erkus (2010) find positive relation between lending scale and bank's net 
interest margin, where large average operating scale leads to higher market risk and credit risk, increasing the possibility of losses. Meanwhile, Fungáčová and Poghosyan (2011) and Hamadi and Awdeh (2012) show the negative effect of bank size on NIM, where large banks with high credit ratings earn their profit from economy of scale and have low NIMs. In Vietnam, banks with large size have advantages they can utilize to raise capital at low cost, such as a large network of operation with many branches, a wide variety of products and service, etc. to make higher profit.

\section{Lending scale (LAR)}

As suggested by Maudos and Guevara (2004), Maudos and Solís (2009), and Hamadi and Awdeh (2012), there exists a positive relation between lending scale and NIM. When market risk and credit risk occur, larger lending scale leads to bigger losses for the bank. In contrast, Hawtrey and Liang (2008), Zhou and Wong (2008), and Kasman et al. (2010) indicate a negative relation between LAR and NIM. Large banks can offer bigger loans with lower interest rate than small ones, leading to lower interest income. In Vietnam, lending is the most significant operation which brings income to banks, so those with big loan size will have higher NIMs.

\section{Credit risk (CR)}

Credit risk refers to the risk that customers are not able to repay the debt at its maturity. Angbazo (1997) predicated that credit risk impacts banks' interest income in a positive manner. Banks which are lending out more money face higher credit risk, and thus have to maintain more reserve, which forces them to charge more interest on their loans in order to make up for the expected losses, resulting in a positive relation (Garza-García, 2010). Quite a few more studies have found the positive relation between credit risk and net interest margin (Maudos \& Guevara, 2004; Dolient, 2005; Maudos \& Solís, 2009; Kasman et al., 2010; Gounder \& Sharma, 2012; Tarus et al., 2012).

\section{Equity capital (CAP)}

According to the IMF (2006), the ratio of equity over total asset is used as one of the recommended indicators to assess the financial health of a commercial bank. Most studies have found positive correlation between CAP and NIM (Brock \& Suarez, 2000; Saunders \& Schumacher, 2000; Maudos \& Guevara, 2004; Doliente, 2005; Hawtrey \& Liang, 2008; Maudos \& Solís, 2009; GarzaGarcía, 2010; Ugur \& Erkus, 2010; Kasman et al., 2010; Fungáčová \& Poghosyan, 2011). Raising the capital will increase the mediate cost of keeping equity more than loans due to taxes and diluting shareholders' rights. The increase in mediate cost is often recovered through an increase in the interest rate spread. Whenever capital is too high, the manager is pressured to increase profit margin.

\section{Loan/deposit ratio (LDR)}

An increase in LDR indicates that a bank has less "onlay" to finance for its growth and protect itself from unexpected withdrawals, especially for banks which depend much on deposits for their growth. When LDR is at a relatively high level, the bank's managers 
rarely desire to give out loans and investments. In addition, they will be more cautious when LDR increases and demand a tightened credit line; therefore, interest rate tends to increase (Rose, 1999). Most empirical studies show that LDR shares a positive correlation with NIM (Ahmad et al., 2011; Hamadi \& Awdeh, 2012).

\section{Management efficiency (CTI)}

High management efficiency helps banks maximize profits and minimize costs, allowing them to reduce the expenses for each dollar of income (Ugur \& Erkus, 2010). High management efficiency also enhances managing responsibility to lessen costs and invest in more earning assets (Angbazo, 1997; Maudos \& Guevara, 2004). Consequently, the higher management effect, the lower CTI and higher NIM. Zhou and Wong (2008), Maudos and Solís (2009), GarzaGarcía (2010), Kasman et al. (2010), Gounder and Sharma (2012), and Hamadi and Awdeh (2012) also used this ratio to measure management efficiency and came to the same conclusion of the negative correlation between management efficiency and bank's NIM.

\section{Interest rate (IR)}

When real interest rate rises, banks tend to raise their lending interest to compensate for borrowing interest. An increase in actual interest rate places borrowers under more pressure and leads to lower asset quality. Therefore, banks may offer higher interest rate to make up for credit risk. Most researchers have found a positive correlation between interest rate and NIM, including Ho and Saunders (1981), Angbazo (1997),
Saunders and Schumacher (2000), Maudos and Guevara (2004), Hawtrey and Liang (2008), Maudos and Solís (2009), Ugur and Erkus (2010), and Hamadi and Awdeh (2012).

These empirical studies mainly focus on banks in one area, a group of countries, such as Southeast Asia, OECD, EU, and Europe, or a particular country, such as the US, Lebanon, Turkey, China, and so forth. There are few investigations into the factors affecting the net interest margin of banks in Vietnam. The data mentioned above mainly feature the period before 2008, whereas the 2010 sample was employed by only a few studies. Particularly, no study can be found using the dataset for the 2008-2014 period.

\section{Methodology and data}

\subsection{Research model}

Based on research models of Fungáčová and Poghosyan (2011), Gounder and Sharma (2012), and Hamadi and Awdeh (2012), this study applies the following model:

$$
\begin{aligned}
& \quad N I M=\beta_{0}+\beta_{1} * S I Z E+\beta_{2} * L A R+\beta_{3} * C R \\
& +\beta_{4} * C A P+\beta_{5} * L D R+\beta_{6} * C T I+\beta_{7} * I R+ \\
& u_{i t}
\end{aligned}
$$

where:

NIM: Net interest margin

SIZE: Bank size

LAR: lending size

$\mathrm{CR}$ : credit risk

CAP: equity capital

LDR: loan-to-deposit ratio

CTI: management efficiency 
IR: interest rate

\subsection{Variable measurements}

The description of how to calculate the studied variables and the expected signs are detailed in Table 1.

\section{Table 1}

Description of variables and expected signs

\begin{tabular}{|c|c|c|c|c|}
\hline Variables & $\begin{array}{l}\text { Nota- } \\
\text { tion }\end{array}$ & Measurement & $\begin{array}{l}\text { Ex- } \\
\text { pected } \\
\text { signs }\end{array}$ & Sources \\
\hline \multicolumn{5}{|l|}{ Dependent } \\
\hline $\begin{array}{l}\text { Net interest } \\
\text { margin }\end{array}$ & NIM & $\begin{array}{l}\text { (interest income - in- } \\
\text { terest expense) / total } \\
\text { earning asset }\end{array}$ & & \\
\hline \multicolumn{5}{|l|}{ Independent } \\
\hline Bank size & SIZE & $\begin{array}{l}\text { logarithm of total as- } \\
\text { set }\end{array}$ & + & $\begin{array}{l}\text { Maudos \& Guevara (2004), } \\
\text { Ugur \& Erkus (2010) }\end{array}$ \\
\hline Lending size & LAR & $\begin{array}{l}\text { loan outstanding / to- } \\
\text { tal asset }\end{array}$ & + & $\begin{array}{l}\text { Hamadi \& Awdeh (2012), } \\
\text { Maudos \& Guevara (2004), } \\
\text { Maudos \& Solís (2009). }\end{array}$ \\
\hline Credit risk & $\mathrm{CR}$ & $\begin{array}{l}\text { credit provision / to- } \\
\text { tal loan outstanding }\end{array}$ & + & $\begin{array}{l}\text { Doliente (2005), Garza-Gar- } \\
\text { cía (2010), Gounder \& } \\
\text { Sharma (2012), Kasman et } \\
\text { al. (2010), Maudos \& Gue- } \\
\text { vara (2004), Maudos \& Solís } \\
\text { (2009), Tarus et al. (2012). }\end{array}$ \\
\hline $\begin{array}{l}\text { Equity } \\
\text { capital }\end{array}$ & CAP & equity / total asset & + & $\begin{array}{l}\text { Doliente (2005), Fungáčová } \\
\text { \& Poghosyan (2011), Garza- } \\
\text { García (2010), Hawtrey \& } \\
\text { Liang (2008), Kasman et al. } \\
\text { (2010), Maudos \& Guevara } \\
\text { (2004), Maudos \& Solís } \\
\text { (2009), Saunders \& Schu- } \\
\text { macher (2000), Ugur \& } \\
\text { Erkus (2010). }\end{array}$ \\
\hline
\end{tabular}




\begin{tabular}{|c|c|c|c|c|}
\hline $\begin{array}{l}\text { Loan-to-de- } \\
\text { posit ratio }\end{array}$ & LDR & $\begin{array}{l}\text { loan outstanding / to- } \\
\text { tal deposit }\end{array}$ & + & $\begin{array}{l}\text { Hamadi \& Awdeh (2012), Ah- } \\
\text { mad et al. (2011) }\end{array}$ \\
\hline $\begin{array}{l}\text { Management } \\
\text { efficiency }\end{array}$ & CTI & $\begin{array}{l}\text { operating cost / total } \\
\text { income }\end{array}$ & - & $\begin{array}{l}\text { Garza-García (2010), } \\
\text { Gounder \& Sharma (2012), } \\
\text { Hamadi \& Awdeh (2012), } \\
\text { Kasman et al. (2010), Mau- } \\
\text { dos \& Solís (2009),Ugur \& } \\
\text { Erkus (2010), Zhou \& } \\
\text { Wong (2008). }\end{array}$ \\
\hline Interest rate & IR & $\begin{array}{l}\text { average } 12 \text {-month in- } \\
\text { terest rate }\end{array}$ & + & $\begin{array}{l}\text { Hamadi \& Awdeh (2012), } \\
\text { Hawtrey \& Liang } \\
\text { (2008),Maudos \& Guevara } \\
\text { (2004), Maudos \& Solís } \\
\text { (2009), Saunders \& Schu- } \\
\text { macher (2000), Ugur \& } \\
\text { Erkus (2010). }\end{array}$ \\
\hline
\end{tabular}

\subsection{Data}

The data in this study were retrieved from the audited financial statements of Vietnamese joint-stock Banks and the Asia-Pacific index report provided by Asia Development Bank over the 2008-2014 period. Up to December 312014 Vietnam has a total of 37 joint-stock commercial banks. The final dataset obtained after elimination of merged banks (SHB and SCB) and those with insufficient or unclear information constitute a random balance panel involving 26 banks and 182 observations, which accounts for approximately $70.3 \%$ of the Vietnamese banking system. Hence, it can be confirmed that those selected banks are appropriate to represent joint-stock commercial banks in Vietnam. Table 2 describes mean, standard deviation, minimum, and maximum values of the studied variables.
Employed in this research are three of the following methods: pooled OLS regression, fixed effects model, and random effects model. In addition, the study uses the test of Hausman (1978) to select the suitable model, after which the variance of the constant error and its autocorrelation are tested to determine the most appropriate regression model. In the last step, the variables are sorted based on the obtained statistics.

\section{Empirical results and discussion}

\subsection{Empirical results}

The study examines the possibility of multicollinearity between the variables by setting up a correlation matrix of the variables and calculating VIF indicators as reported in Table 3 .

The results shows that none of the correlation coefficient among pairs of variables 


\section{Table 2}

Descriptive statistics

\begin{tabular}{lcccc}
\hline \multicolumn{1}{c}{ Variables } & Mean & Standard deviation & Min & Max \\
\hline NIM & 0.0292 & 0.0145 & -0.0063 & 0.0961 \\
SIZE & 17.7138 & 1.2790 & 14.5026 & 20.3096 \\
LAR & 0.5084 & 0.1481 & 0.1561 & 0.9442 \\
CR & 0.0132 & 0.0061 & 0.0021 & 0.037 \\
CAP & 0.1311 & 0.0910 & 0.0426 & 0.6141 \\
LDR & 0.9427 & 0.3859 & 0.3719 & 3.5187 \\
CTI & 0.5041 & 0.1554 & 0.2251 & 1.1152 \\
IR & 0.1084 & 0.0202 & 0.0762 & 0.1346 \\
\hline
\end{tabular}

Table 3

Correlation matrix of variables

\begin{tabular}{lcccccccc}
\hline & SIZE & LAR & CR & CAP & LDR & CTI & IR & VIF \\
\hline SIZE & 1 & & & & & & 2.65 \\
LAR & -0.0446 & 1 & & & & & 1.42 \\
CR & 0.4635 & -0.0289 & 1 & & & & 1.35 \\
CAP & -0.7056 & 0.0871 & -0.2586 & 1 & & & 3.17 \\
LDR & -0.4101 & 0.4517 & -0.2100 & 0.6412 & 1 & & 2.44 \\
CTI & -0.0617 & -0.0718 & 0.1261 & -0.0129 & -0.0928 & 1 & 1.22 \\
IR & -0.2358 & -0.0404 & -0.1877 & 0.1299 & 0.1729 & -0.3404 & 1 & 1.28 \\
\hline
\end{tabular}

exceeds 0.8. The largest VIF index of the independent variables in this study is 3.17 , less than 5 (Gujarati, 2004). Therefore, the multicollinearity problem potentially existing in the used models is negligible.

The results of the regression model are shown in Table 4. At this stage we conduct the Hausman test to select the appropriate model. The Hausman test results give the statistical value chi-square of 20.87 with prob.chi-square of 0.0040 . As can be seen, Prob is more than 5\%, which allows us to reject the null hypothesis $\mathrm{H}_{0}$, and accept the hypothesis $\mathrm{H}_{1}$ in Hausman test that no correlation exists between the random factor of the bank and independent variables. Thus, 
the study will select the fixed effects regression model (FEM) to analyze the results. Next, we test for the variance of the constant error as well as its autocorrelation.

The test results of the variance of the constant error (White test), prob.chi-square = 0.000 , less than $5 \%$ and the result of error autocorrelation (Breusch-Godfrey test), prob.F $(1.25)=0.000$, also less than $5 \%$. These results show that the model suffers both heteroskedasticity and autocorrelation of errors. According to Wooldridge (2002), the solution to these problems is to apply the regression model with the general least squares (GLS) method. Table 4 presents the regression results of using GLS method to estimate the regression coefficients.

\subsection{Discussion}

In this section, the study highlights the results of the regression model using GLS method. The first variable to be considered, lending scale (LAR), shares a positive correlation with NIM. The more Vietnam's commercial banks enlarge their lending scale, the higher the NIM, which consistent with previous findings of Maudos and Guevara (2004) in Europe, Maudos and Solís (2009) in Mexico, and Hamadi and Awdeh (2012) in Lebanon. In Vietnam lending makes up the most traditional and major ac-

\section{Table 4}

Regression results

\begin{tabular}{|c|c|c|c|c|}
\hline \multirow{2}{*}{ Variables } & \multicolumn{4}{|c|}{ Model } \\
\hline & Pooled (p-value) & FEM (p-value) & REM (p-value) & GLS (p-value) \\
\hline Constant & $-0.0411(0.030)$ & $-0.1165(0.001)$ & $-0.0567(0.012)$ & $-0.0277(0.131)$ \\
\hline SIZE & $0.0026 * * *(0.004)$ & $0.0061 * * *(0.000)$ & $0.0032 * * *(0.005)$ & $0.0015(0.113)$ \\
\hline LAR & $0.0213 * * *(0.000)$ & $0.0265 * * *(0.001)$ & $0.0193 * * *(0.002)$ & $0.0218 * * *(0.000)$ \\
\hline CR & $0.1571(0.236)$ & $0.3014 * *(0.045)$ & $0.2806 * *(0.042)$ & $0.2245 * *(0.035)$ \\
\hline CAP & $0.1203 * * *(0.000)$ & $0.1072 * * *(0.000)$ & $0.1076 * * *(0.000)$ & $0.0852 * * *(0.000)$ \\
\hline LDR & $0.0028(0.330)$ & $0.0037(0.170)$ & $0.0043(0.105)$ & $0.0015(0.543)$ \\
\hline CTI & $-0.0206 * * *(0.000)$ & $-0.0191 * * *(0.000)$ & $-0.0175 * * *(0.000)$ & $-0.0166^{* * *}(0.000)$ \\
\hline IR & $0.0360(0.358)$ & $0.1072 * * *(0.004)$ & $0.0623 *(0.065)$ & $0.0992 * * *(0.000)$ \\
\hline Adjusted $\mathrm{R}^{2}$ & 0.5806 & 0.4726 & 0.4558 & - \\
\hline $\begin{array}{l}\text { F-statis- } \\
\text { tic/Wald.Chi }{ }^{2}\end{array}$ & $36.80(0.000)$ & 19.08(0.000) & $176.45(0.000)$ & $178.20(0.000)$ \\
\hline Hausman test & $20.87 * * *(0.0040)$ & & & \\
\hline
\end{tabular}

Note: $*$, **, and $* * *$ denote significance of $10 \%, 5 \%$, and $1 \%$ respectively. 
tivities of banks (about 70-80\% of bank operations). Therefore, most banks tend to focus on lending activities as one of their main channels of profits.

As expected, credit risk (CR) has the strongest positive correlation with the NIM of Vietnamese commercial banks. This result indicates that in Vietnam banks accepting higher credit risk will have higher NIMs, which is in line with Angbazo (1997), Maudos and Guevara (2004), Dolient (2005), Maudos and Solís (2009), Garza-Garcia (2010), Kasman et al. (2010), Gounder and Sharma (2012), and Tarus et al. (2012).

Next, equity capital (CAP) is positively associated with NIM, demonstrating the importance of scale of equity in improving the Vietnamese commercial banks' NIMs. This study shows that better capitalized banks face lower risk of default. Moreover, a strong capital structure is essential for banks operating in developing economies, as it provides more power for them to survive during different times of financial crisis and increase the level of security provided to depositors when faced with adverse conditions of macroeconomic instability. These results are consistent with previous research findings, including Brock and Suarez (2000), Saunders and Schumacher (2000), Maudos and Guevara (2004), Doliente (2005), Hawtrey and Liang (2008), Maudos and Solís (2009), Garza-Garcia (2010), Kasman et al. (2010), Ugur and Erkus (2010), and Fungacova and Poghosyan (2011).

Whether management efficiency is good or not depends on the ratio of operating cost to total income (CTI). The result pointed out that CTI has a negative correlation with
NIM, consistent with earlier findings of Angbazo (1997), Maudos and Guevara (2004), Zhou and Wong (2008), Maudos and Solís (2009), Garza-Garcia (2010), Kasman et al. (2010), Ugur and Erkus (2010), Gounder and Sharma (2012), and Hamadi and Awdeh (2012). During the period of 2008-2012, the time of financial crisis, the Vietnamese economy had been facing many difficulties, banks had to go through largescale reorganizations of their administration and operating systems in order to improve management efficiency and clearly define the responsibilities as well as authorities of departments at different levels. Up to now, Vietnamese banks' administration and management efficiency has become more professional with further access to management knowledge from technology transfers and strategic cooperation.

Finally, as shown by our findings, interest rate (IR) has positive relation to NIM, which reflects the situation of the Vietnamese banking system in the studied period when the rise in interest rates led to an increase in the cost of raising banks' capital. Furthermore, banks tend to expand their system, increasing operating costs, including staff costs. Compared with other sectors of the entire economy, the cost of banking staff reaches a high level, and it is translated into the output interest of the bank, leading to high interest rates being given to borrowers. The results are consistent with those of the studies formerly conducted by Ho and Saunders (1981), Angbazo (1997), Saunders and Schumacher (2000), Maudos and Guevara (2004), Hawtrey and Liang (2008), Maudos and Solís (2009), Ugur and Erkus (2010), 
and Hamadi and Awdeh (2012).

\section{Conclusion and implications}

Using a panel dataset, this paper examines a total of seven factors that affect the net interest margin of commercial banks in $\mathrm{Vi}$ etnam from 2008 to 2014. After analyzing and testing hypotheses violations, the study has applied different regression models with GLS method. The empirical results indicate that in Vietnam lending scale (LAR), credit risk (CR), scale of equity (CAP), and interest rate (IR) have positive effects on the NIM of banks, which, in turn, is negatively affected by management efficiency (CTI). Bank size (SIZE) and loan-to-deposit ratio (LDR) are statistically insignificant to NIMs of these Vietnamese commercial banks.

From the results reported in Table 4, some of the following solutions can be suggested to enhance the net interest margin of Vietnam's joint-stock commercial banks:

\subsection{Widening lending scale}

Since lending scale has a positive effect on NIM, increasing bank loan means increasing NIM of commercial banks. However, if banks widen lending scale without tight control, the consequence is of great concerns (e.g., it may lead to imbalanced safety or increased inflation). To sum up, along with expanding their lending scale, banks need to guarantee that credit security is in accordance with the State Bank's regulations.

\subsection{Managing credit risk}

Credit risk is also demonstrated to have a positive impact on NIM of Vietnamese commercial banks. The higher the credit risk, the higher the NIM; thus, in order to increase the NIM banks often have to manage their credit risk well while not focusing on high-risk loans because high profit may create principal loss and insecurity.

\subsection{Increasing equity}

Owned equity scale impacts NIM of commercial banks in the same direction. As the scale of owned equity of one bank grows, NIM also grows. Several strategic policies can be adopted to increase equity capital such as issuing additional shares in the market; selling shares to strategic partners which are local banks, foreign banks, domestic corporations, and foreign investors; implementing dividends by shares; using the equity surplus of the last year to raise funds for this year; or setting up the fund from profits of previous years. Depending on the strength and the specific situation in each period, banks will have different methods to raise capital that assure sustainable fund as well as the benefit of shareholders in the bank.

\subsection{Improving the efficiency of the man- agement of joint-stock commercial banks}

Management effectiveness has an opposite impact on NIM. Increasing management efficiency results in decreased NIM, because when bank control is too tight, the consequence is that lending size will be narrowed. To ensure effective management, commercial banks need to restructure and rearrange each of their business functions, governance, and administration; they need to logically sort out and arrange the development of personnel staff and business managers 
who are highly qualified, with great sense of responsibility and good ethics. They also need to modernize the IT system and develop the risk management system in accordance with the principles of the Basel Committee's standards.

\subsection{Considering interest issue}

According to the findings, there exists a positive impact of interest ratio on NIM of joint-stock commercial banks in Vietnam. An increase in the interest ratio should accordingly give rise to the NIM. However, in terms of economic nature, the loan interest rate is derived from the operating profit of the business. Hence, when making interest rate policy, banks should: (i) analyze and accurately evaluate the rate of return of businesses to determine the proper lending rate and to ensure win-win cooperation; (ii) concerning lending rates, enhance forecasting and advisory abilities to help customers prevent and limit their risks; and (iii) provide derivative products as hedging instruments for interest rate risk as could be encountered by businesses

\section{References}

Ahmad, R., Shahruddin, S. S, \& Tin, L. M. (2011). Determinants of bank profits and net interest margins in East Asia and Latin America. Working paper series. Retrieved 10 August 2013 from http://papers.ssrn.com/sol3/papers.cfm?abstract_id=1912319

Angbazo, L. (1997). Commercial bank net interest margins, default risk, interest rate risk and off-balance sheet banking. Journal of Banking and Finance, 21(1), 55-87.
Brock, P. L., \& Suarez, L. R. (2000). Understanding the behavior of bank spreads in Latin America. Journal of Development Economics, 63(1), 113-134.

Doliente, J. S. (2005). Determinants of bank net interest margins in Southeast Asia. Applied Financial Economic Letters, 1(1), 53-57.

Fungáčová, Z., \& Poghosyan, T. (2011). Determinants of bank interest margins in Russia: Does bank ownership matter? Economic Systems, 35(4), 481-495.

Garza-García, J. G. (2010). What influences net interest rate margins? Developed versus developing countries. Banks and Bank Systems, 5(4), 32-41.

Golin, J. (2001). The bank credit analysis handbook: A guide for analysts, bankers and investors. Singapore: John Wiley \& Sons (Asia) Pre Ltd.

Gounder, N., \& Sharma, P. (2012). Determinants of bank net interest margins in Fiji, a small island developing state. Applied Financial Economics, 22(19), 1647-1654.

Gujarati, D. (2004). Basic econometrics (4 ${ }^{\text {th }}$ Ed.). India: Tata McGraw Hill.

Hamadi, H., \& Awdeh, A. (2012). The determinants of bank net interest margin: Evidence from the Lebanese banking sector. Journal of Money, Investment and Banking, 23(3), 8598.

Hawtrey, K., \& Liang, H. (2008). Bank interest margins in OECD countries. North American Journal of Economics and Finance, 19(3), 249-260.

Hempel, G., Coleman, A., \& Simonson, D. (1986). Bank management: Text and cases $\left(2^{\text {nd }}\right.$ Ed.). NY: John Wiley \& Sons.

Ho, T. S., \& Saunders, A. (1981). The determinants of bank interest margins: Theory and empirical evidence. Financial Quantitative Analysis, 16(4), 581-600. 
IMF. (2006). Financial soundness indicators compilation guide. Retrieved 15 June 2013 from http://www.imf.org/external/pubs/ft/fsi/guide/2006/index.htm

Kasman, A., Tunc, G., Vardar, G., \& Okan, B. (2010). Consolidation and commercial bank net interest margins: Evidence from the old and new European Union members and candidate countries. Economic Modelling, 27(3), 648-655.

Maudos, J., \& Guevara, J. F. D. (2004). Factors explaining the interest margin in the banking sectors of the European Union. Journal of Banking and Finance, 28(9), 2259-2281.

Maudos, J., \& Solís, L. (2009). The determinants of net interest income in the Mexican banking system: An integrated model. Journal of Banking and Finance, 33(10), 1920-1931.

Rose, P. S. (1999). Commercial bank management. Boston, Mass: Irwin/McGraw-Hill.

Saunders, A., \& Schumacher, L. (2000). The determinants of bank interest margins: An international study. Journal of International
Money and Finance, 19(6), 813-832.

Sensarma, R., \& Ghosh, S. (2004). Net interest margin: Does ownership matter? Vikalpa: The Journal for Decision Makers, 29(1), 4148.

Tarus, D. K., Chekol, Y. B., \& Mutwol, M. (2012). Determinants of net interest margins of commercial banks in Kenya: A panel study. Procedia Economics and Finance, 2, 199-208.

Ugur, A., \& Erkus, H. (2010). Determinants of the net interest margins of banks in Turkey. Journal of Economic and Social Research, 12(2), 101-118.

Wooldridge, J. (2002). Econometric analysis of cross section and panel data. Cambridge, MA: MIT Press.

Zhou, K., \& Wong, M. C. S. (2008). The determinants of net interest margins of commercial banks in mainland China. Emerging Markets Finance Trade, 44(5), 41-53. 